\title{
Bushke-Lowenstein Tumor Transforming To an Aggressive Squamous Cell Carcinoma: A Case Report with Literature Review
}

Khadija Elboukhari $^{1{ }^{*}}$, Sara Elloudi ${ }^{1}$, Sara Dahhouki ${ }^{1}$, Hanane Baybay ${ }^{1}$, Sara Elloudi ${ }^{1}$, Fatima Zahra Mernissi ${ }^{1}$, Zahra

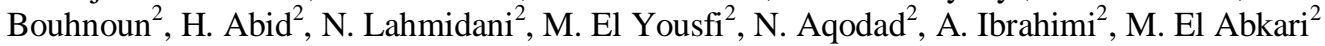

${ }^{1}$ Departement of Dermatology, University Hospital of Fez, Morocco

${ }^{2}$ Departement of hepato-gastro-enterology, University Hospital of Fez, Morocco

DOI: $10.36348 /$ sjmps.2019.v05i11.016 $\quad$ | Received: 31.10 .2019 | Accepted: 07.11.2019| Published: 30.11 .2019

*Corresponding author: Khadija Elboukhari

\section{Abstract}

Bushke-Lowenstein Tumor Giant or Condyloma Acuminata is a rare neoplasm induced by an oncogenic human papilloma virus (HPV 11 and 6). It is a sexually transmitted disease. Despite of its indolent character it can probably degenerate to an aggressif epidermoid carcinoma like in our observation. We report the case of a patient who developed this tumor with locoregional destruction. The Aim of this work is to describe this pathology via a literature review.

Keywords: Bushke-lowenstein tumor, Condyloma Acuminata, Squamous Cell Carcinoma.

Copyright @ 2019: This is an open-access article distributed under the terms of the Creative Commons Attribution license which permits unrestricted use, distribution, and reproduction in any medium for non-commercial use (NonCommercial, or CC-BY-NC) provided the original author and source are credited.

Abbreviation: BLT: Buschke and Lowenstein Tumor, HPV: human papilloma virus

\section{INTRODUCTION}

Giant Condyloma Acuminata or BushkeLowenstein Tumor is a rare neoplasm induced by an oncogenic human papilloma virus (HPV 11 and 6). It is a sexually transmitted disease, which can probably degenerate after a long duration of evolution especially when there is other risk factors of anal carcinoma. We report the case of a patient carrying this tumor and presenting a locally advanced stage of squamous cell carcinoma.

\section{CASE PRESENTATION}

It's about a patient of 62 years, smoking for 30 year, with a history of heterosex. presented bilateral inguinal masses, the right one was fistulized with purrulous and foul smelling discharge, a history of vegetative lesions in the anal margin growing up for 20 years has been discovered. The clinical examination found a foul-smelling cauliflower-shaped tumor taking on the anal margin and the perianal area, it was blinded and obturating the anus (Figure-1).

The ganglion examination found an ulceroburging tumor of the right inguinal area and a large left inguinal lymphadenopathy very inflammatory and painful (Figure-2). This patient underwent skin biopsy at the level of the inguinal tumor (Figure-3), returned to non-keratinizing and moderately differentiated squamous cell carcinoma infiltrant, while anal margin biopsy was in favor of a condyloma (Figure-4).

Our patient underwent a rectoscopy which did not objectify extension in the rectal mucosa. In the extension assessment, the ultrasound scan found a huge tumor-like left inguinal lymphadenopathy, while thoraco-abdominopelvic tomodensitometry showed infiltration of the rectal wall with perirectal necrosis.

After in institutional tumor board with surgeons, medical and radiation oncologists. Only a palliative chemotherapy has been indicated for our patient. 


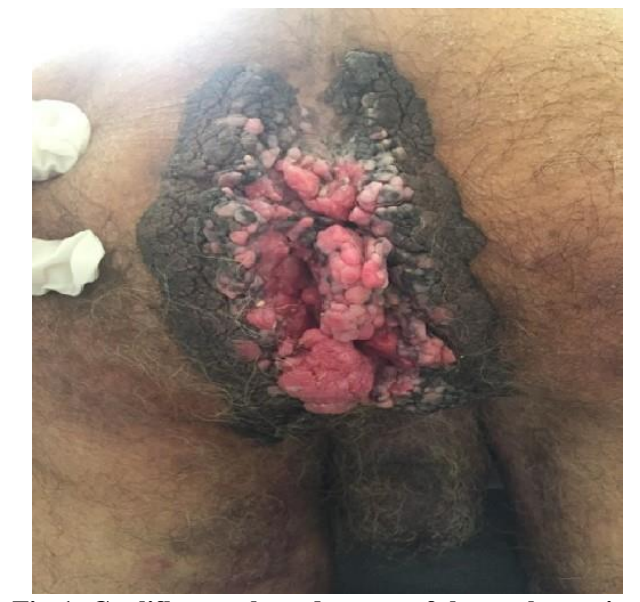

Fig-1: Cauliflower-shaped tumor of the anal marging

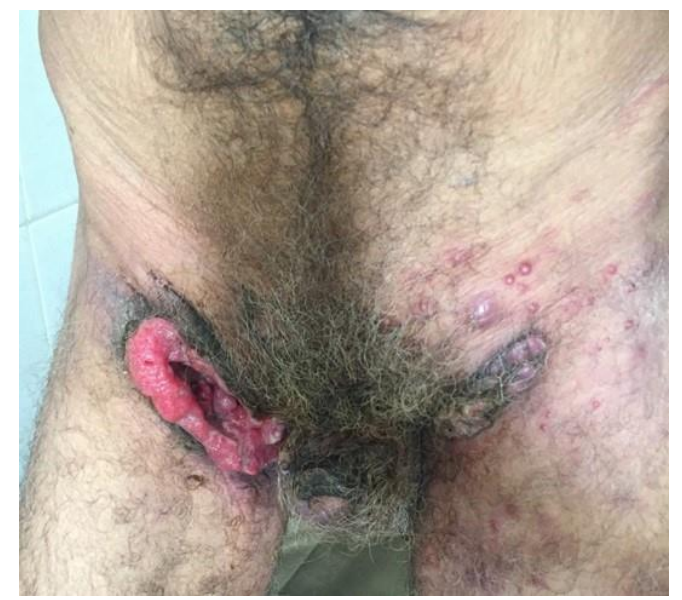

Fig-2: An ulceroburging tumor of the right inguinal area

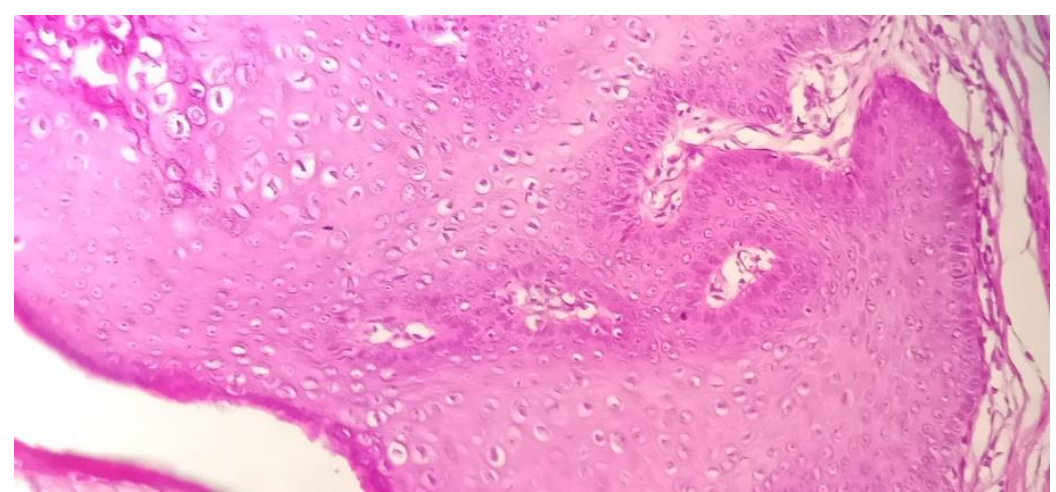

Fig-3: HES stain G x 100 => Epithelial proliferation with papillar architecture and a large number of koilocytes

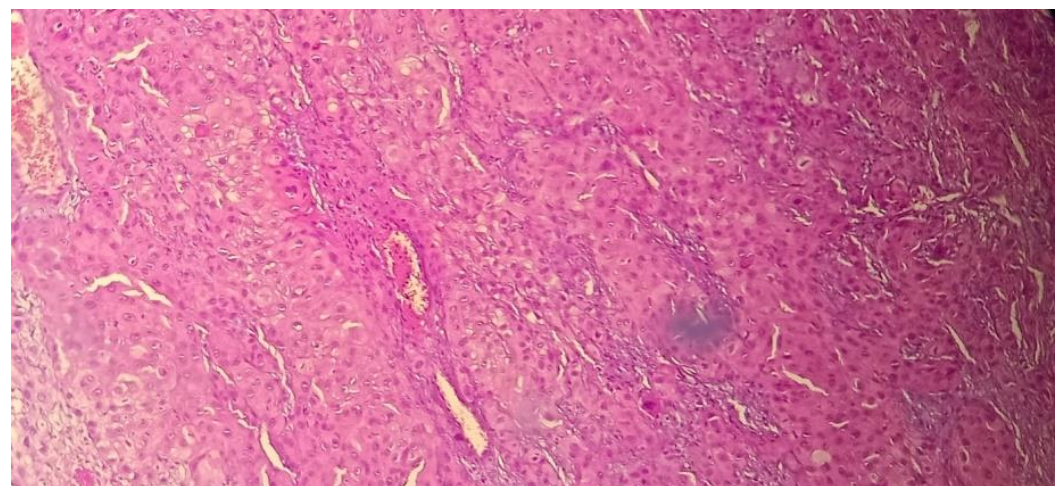

Fig-4: HES stain G x 100 => malignant infiltrarting proliferation without signs of keratinization

\section{DISCUSSION}

First described in 1925 by Buschke and Lowenstein [1] as carcinomalike condylomata acuminata of the penis. BLT are more rarely seen in the anal location [2].

Buschke-Lowenstein tumors also known as verrucous carcinoma [3] are slow-growing giant condylomata accuminata of the anogenital region [4]. Reaching $0,1 \%$ of the population in sexual activity [5] and more frequently between the 4th and 6th deceny [6] with a male predominance [7, 8]. Oncogenic human papillomavirus types 6 and 11 are the major factors of this rare tumor [4] other risk factors have been described such as smoking, Multiple sexual partner and human immunity deficiency $[9,10]$. The tumor appears like a large erythematous and cauliflower-like mass, or a rooster's crest [4]. It evolves slowly, and do not regress spontaneously [11].

The degenerative frequency of a giant condyloma is significant, estimated at $30 \%$ [12]. It can evolve to a micro-invasive carcinoma. In other cases, a transformation to an invasive squamous cell carcinoma with a more aggressive necrotic character is possible as happent to our patient.

Histologically, the exact terminology still controverted. In fact there is some authors who considered the BLT a well differentiated squamous cell carcinoma and others defined it like a transition form 
between Condyloma Acuminata and Squamous Cell Carcinoma [13, 14].

The radical surgical excision of the tumor is the treatment of choice [15] and must be as wide as possible in order to ovoid recurrences [16]. The use of radiotherapy have showed its efficiency but limited by the risk of degeneration into anaplastic carcinoma [15, 17]. Few reported cases have been successfully treated with long term intralesional interferon alpha-2b $[13,18$, 19].

Chemotherapy based on 5-fluorouracil and cisplatin, associated or not to radiotherapy was also reported in some series and reported cases [15].

It have been reported that preoperative chemoradiation followed by radical surgery is an efficient therapeutic modality and could have no recurrences [20-22].

\section{CONCLUSION AND PERSPECTIVE}

Giant Condyloma Acuminata of the anal margin is a rare tumor, characterized by its local aggressiveness. The histological terminology still a debate between authors. There is no consensus of treatment of this entity but a multidisciplinary contribution for the management of this tumor is necessary.

The main perspective in this work is to show the risque of transformation from an indolent to an aggressive tumor with high risk of metastasis. The management of this disease should be the earliest possible by the surgery. Primary prevention consists on sensitization of the adult population to this sexually transmitted disease

\section{REFERENCES}

1. Buschke, A., \& Loewenstein, L. (1925). Über carcinomähnliche Condylomata acuminata des Penis. Journal of Molecular Medicine, 4(36), 1726-1728.

2. Steffen, C. (2006). The men behind the eponymAbraham Buschke and Ludwig Lowenstein: giant condyloma (Buschke-Loewenstein). The American journal of dermatopathology, 28(6), 526-536.

3. Uth, A. O. (2012). Perianal Buschke-Löwenstein tumour. Ugeskrift for laeger, 174(23), 1616-1617.

4. Fai, E. K., Bhutta, H. A., \& Ali, K. (2019). Progression of a Buschke-Lowenstein tumor into invasive squamous cell carcinoma. Journal of the American Academy of PAs, 32(6), 1-4.

5. Gillard, P., Vanhooteghem, O., Richert, B., \& De La Brassinne, M. (2005). Buschke-Löwenstein tumor. Ann Dermatol Venereol, 132: 98-99.

6. Fai, E. K., Bhutta, H. A., \& Ali, K. (2019). Progression of a Buschke-Lowenstein tumor into invasive squamous cell carcinoma. Journal of the American Academy of PAs, 32(6), 1-4.

7. Njoumi, N., Tarchouli, M., Ratbi, M. B., Elochi, M. R., Yamoul, R., Hachi, H., \& Bougtab, A. (2013). La tumeur de Buschke-Lowenstein anorectale: à propos de 16 cas et revue de la littérature. The Pan African Medical Journal, 16.

8. Spinu, D., Rădulescu, A., Bratu, O., Checheriţă, I. A., Ranetti, A. E., \& Mischianu, D. (2014). Giant condyloma acuminatum-Buschke-Lowenstein disease-a literature review. Chirurgia (Bucharest, Romania: 1990), 109(4), 445-450.

9. Shenoy, S., Nittala, M., \& Assaf, Y. (2019). Anal carcinoma in giant anal condyloma, multidisciplinary approach necessary for optimal outcome: Two case reports and review of literature. World journal of gastrointestinal oncology, 11(2), 172-180.

10. Assi, R., Hashim, P. W., Reddy, V. B., Einarsdottir, H., \& Longo, W. E. (2014). Sexually transmitted infections of the anus and rectum. World Journal of Gastroenterology: WJG, 20(41), 15262.

11. Kim, H. G., Kesey, J. E., \& Griswold, J. A. (2018). Giant anorectal condyloma acuminatum of Buschke-Löwenstein presents difficult management decisions. Journal of surgical case reports, $2018(4)$, rjy058.

12. Qarro, A., Ali, A. A., Choho, A., Alkandry, S., \& Borki, K. (2005, February). Tumeur de BuschkeLowenstein à localisation anorectale:(À propos de trois cas). In Annales de chirurgie, 130(2), 96-100. Elsevier Masson.

13. Geusau, A., Heinz-Peer, G., Volc-Platzer, B., Stingl, G., \& Kirnbauer, R. (2000). Regression of deeply infiltrating giant condyloma (BuschkeLöwenstein tumor) following long-term intralesional interferon alfa therapy. Archives of dermatology, 136(6), 707-710.

14. Creasman, C., Haas, P. A., Fox, T. A., \& Balazs, M. (1989). Malignant transformation of anorectal giant condyloma acuminatum (BuschkeLoewenstein tumor). Diseases of the colon \& rectum, 32(6), 481-487.

15. Sandhu, R., Min, Z., \& Bhanot, N. (2014). A gigantic anogenital lesion: Buschke-Lowenstein tumor. Case reports in dermatological medicine, 2014.

16. Chu, Q. D., Vezeridis, M. P., Libbey, N. P., \& Wanebo, H. J. (1994). Giant condyloma acuminatum (Buschke-Lowenstein tumor) of the anorectal and perianal regions. Diseases of the colon \& rectum, 37(9), 950-957.

17. Wu, C. F., Lee, C. H., Hsi, E., Chen, C. H., \& Tang, J. Y. (2014). Interval between intra-arterial infusion chemotherapy and surgery for locally advanced oral squamous cell carcinoma: impacts on effectiveness of chemotherapy and on overall survival. The Scientific World Journal, 2014. 
18. Tsambaos, D., Monastirli, A., Kapranos, N., Georgiou, S., Pasmatzi, E., \& Berger, H. (1994). Intralesional interferon alpha-2b therapy for Buschke-Loewenstein tumour. Acta dermatovenereologica, 74(6), 457-459.

19. Zachariae, H., Larsen, M., \& Søgaard, H. (1988). Recombinant interferon alpha-2a (Roferon-A) in a case of Buschke-Löwenstein giant condyloma. Dermatology, 177(3), 175-179.

20. Hyacinthe, M., Karl, R., Coppola, D., Goodgame, T., Redwood, W., Goldenfarb, P., ... \& Marcet, J. (1998). Squamous-cell carcinoma of the pelvis in a giant condyloma acuminatum: use of neoadjuvant chemoradiation and surgical resection. Diseases of the colon \& rectum, 41(11), 1450-1453.

21. Butler, T. W., Gefter, J., Kleto, D., Shuck, E. H., \& Ruffner, B. W. (1987). Squamous-cell carcinoma of the anus in condyloma acuminatum. Diseases of the colon \& rectum, 30(4), 293-295.

22. Shenoy, S., Nittala, M., \& Assaf, Y. (2019). Anal carcinoma in giant anal condyloma, multidisciplinary approach necessary for optimal outcome: Two case reports and review of literature. World journal of gastrointestinal oncology, 11(2), 172-180. 